\title{
Class Management Through the Literacy Learning Buhuta Walama Lo Tihedu in the Province Gorontalo Indonesia
}

\author{
Abdul Rahmat \\ Departement of Nonformal Education \\ Gorontalo State University \\ Gorontalo, Indonesia \\ Email.abdulrahmat@ung.ac.id
}

\author{
Halim K. Malik \\ Departement of Nonformal Education \\ Gorontalo State University \\ Gorontalo, Indonesia \\ halimmalik@ung.ac.id
}

\begin{abstract}
Recently, In a class all aspects of learning to meet and proceed; with all his teachers; students with all the background and potential; curriculum with all its components; method by all approach; media with all devices; with any source of learning materials to meet and interact in the classroom. Meanwhile, the learning outcomes determined also everything that happens in the classroom. Therefore, class to Be in good, professional, and sustainable. This study aims to examine the management model class in literacy learning through buhuta approach walama lo tihedu in Gorontalo Province. This research was conducted in Gorontalo province, carried out during the year, namely 2015-2016. This research is classified into types Research and Developmet. Subjects were illiterate residents learned basic level in Gorontalo province. The results showed that the problems that often arise in the application class management due to less cohesive class, differences in ethnicity, gender, behavior deviations. It happened because it has not used this forum for communication for community-based culture as a means of resolving illiteracy is approach buhuta walama lo tihedu that utilizes raised illiterate who are members of a neighborhood association intervened to program basic literacy so that they can read, write, count, Indonesian, and a knowledge base that can provide opportunities to actualize themselves. The role of chairman of the neighborhood since the data collection, as a tutor and encourage participation and motivator for this citizens learn at a basic level of literacy programs. For the RT is the person who directly deal with the public and who saw the real conditions in society.
\end{abstract}

Keywords-order a classroom atmosphere, effective class organization and achievement of learners

\section{INTRODUCTION}

Basic literacy education is an education for citizens who are illiterate to read, write, calculate, Indonesian, and the knowledge base that can provide opportunities to actualize themselves. The service is realized in an integrated literacy education with efforts to improve the social, economic, and cultural more helpful and empowering the community with a more effective and efficient. In 2014 the figure illiterate aged 15-59 years in Gorontalo Province amounted to 15122 inhabitants and has intervened through the budget as much as
3,000 . So at the end of 2014 the number of illiterate in the province of Gorontalo be 12122 inhabitants.

Strategic issues that appear in connection with the completion of illiteracy basic level include: lack of accurate data on population with illiteracy, lack of socialization about the program completion of illiteracy, lack of creative methods used in the completion of the illiterate, still reluctance of people with illiteracy to follow program completion illiterate, has not been exploited container-based communications community culture as a means of resolving illiterate. Handling the completion of illiteracy is still conventional so it takes a long time and less attractive to people with illiteracy which embarrassed so reluctant to follow the program.

Seeing these conditions the government tried to hammer out a maximum of illiterate communities through literacy programs including the Basic Level in North Gorontalo District totaling 1,490 people. Especially for the District Ipilo village Gentuma Kingdom as the location for the implementation of the project area changes based on the data collection was done where a population of 1,042 inhabitants with a number of heads of household is 290 and that bears illiterate basic level amounted to 147 people. From the strategic issues mentioned above, the chosen priorities to accelerate the completion of basic illiteracy is not exploited container-based communications community culture as a means of resolving illiterate ground level. One of the specific local Gorontalo society that can be used as an approach in the completion of a basic level of illiteracy is approach buhuta walama lo tihedu. (Dadhich and K. T. Bhal,, (2008)

Completion illiteracy rate Buhuta basic approach Walama Lo Tihedu is locally specific approach of Gorontalo province where buhuta implies bond, walama implies binding and tihedu implies neighbors. So it can be interpreted as the neighborhoods that take advantage of the neighborhood in the completion of a basic level of illiteracy. With illiterate citizens who are members of one of the neighborhood intervened with basic literacy program so that they can read, write, calculate, Indonesia, and the knowledge base that can provide opportunities to actualize themselves. 
Neighborhood (RT) is a community institution composed of families formed through compromise / consensus of society in certain locations in order to help the government services and community development. The role of chairman of the neighborhood since the data collection, as a tutor and encourage participation and motivator for this citizens learn at a basic level of literacy programs. For the RT is the person who directly deal with the public and who saw the real conditions in society. (Fabi, B.; Raymond, L. \& Lacoursiere, R. (2014).

Implementation of this program is different from the conventional ways that are now carried out is for 6 months in completing the completion of tuna akasara basic level. Meanwhile, if using a locally specific approach Buhuta Walama Lo Tihedu takes two months. This can reduce the time of completion of the illiterate and cost savings so as to accelerate the completion of a basic level of illiteracy.

Seeing the above mentioned conditions, the importance of efforts to improve the ability beraksara society by the application of a specific penedekatan local. So that the area of the proposed changes into the project changes are: "Developing Learning Model to Accelerate Completion Tuna Alphabet Basic Level Approach Through Buhuta Walama Lo Tihedu In the village Ipilo Gentuma Raya Subdistrict Gorontalo Regency Gorontalo Province". Due to the learning of literacy is at the heart of lifelong education to improve the human development index.

\section{LITERATURE REVIEW}

Theoretically, there are four ways people look at teaching practices, which is a process, methodology, program and movement. Malcolm Knowles (1978) describes the movement pembelajaan as the process is, the which emphasizes learning process as what happens during the course of a learning experience in learning Attaining a given product or outcome. Understanding of learning as a process not seen how many results were achieved, but how far the process is done. As a teaching methodology is working a particular goal will be achieved. The emphasis of the methodology is a combination of all the elements, techniques, manner of presentation, shape, and supporting tools that is processed as a mirror of philosophy and paradigm adopted. End to be achieved from the process is emphasized in this concept. On the other hand learning can also be seen as a program. That is pembelajaan also emphasized on the activity or the activity applied. The latter pembelajaan also a dynamic movement and programmed. It saw learning as a determination to achieve certain goals.

Adult learning (andragogy) as an educational philosophy and social theory the term has been used in 1833, by Alexander Kapp, a school tutor "grammar" German (Knowles, M. (1978: 81). In the Netherlands the term was introduced by Prof. TT Ten Have in college, in 1954. in 1959 he publish it, and since 1966 Andragogi officially opened at the University of Amsterdam until the doctoral program. in the next phase, since the 1970s the theory of andragogy is increasingly being used in Europe, such as Holland, French, and English. Even in the continental United States, Venezuela, and Canada.
Likewise in Asia, namely India (University of Madras). in Germany alone has opened the Department of Andragogy in the same year (Syamsu Mappa \& Anisah Basleman, 1994: 110 ) .

Andragogy term comes from the Greek aner meaning adults, and agogus it means to lead. Androgogi, that is the science guide $/$ educate people; aner, andros = man; agoo = lead, educate) is the science of the human form; which is formed of the whole personality, so that it is capable of independently in their social environment. Thus, adragogi can be formulated as an art and science to help citizens do education. (Zaenuddin Arief, 1986: 90) According Suwarto, 1995: 13) andragogy as a theory of learning is an educational process that helps the residents (adults) to find himself and use them in situations to encourage the development of a person, organization, or community.

As a theory of education, andragogy has an emphasis on four key assumptions (Sudjana, 1993: 51), namely: First, the difference in changes in self-concept. The concept of self are the views and feelings about ourselves. The second assumption, the difference in the role experience. As individuals grow mature will collect a large amount of experience in which it caused itself to be a rich source of learning, and at the same time giving him a broad base to learn something new. The third assumption, readiness to learn. learning it directly or indirectly, implicitly or explicitly, certainly played a major role in preparing citizens to fight for their existence in society. The fourth assumption, the study orientation. Residents learn inclined orientation centered on solving the problems of life. This is because adult learning as if it needs to deal with his problems. Therefore, the orientation of education is an increased ability to solve problems that they face life.

Learning is mempertegus behavior through the experience. According to this understanding, learning can be understood as an effort to help improve the ability of a person or society as a social system that independently capable of directing and accelerating social changes leading to a condition that aspired (M. Ngalim Purwanto, 2002: 51).

Skinner (1958) provides a definition of learning "Learning is a process of progressive adaptation behavior". From these definitions can be explained that learning is a process that is progressive behavioral adaptations. This means that as a result of learning their progressive nature, a tendency toward better than the previous situation. The principle of operant conditioning Skinner B.F begin early 1930s, at the time the release of S-R theory. At the time of the release of the theories S-R. at that time kondisian classic models of Pavlov has a strong influence on the conduct of the study. According to Skinner explanation S-R about the change in behavior is not equipped to explain how organisms interact with their environment. He filed a paradigm that includes both types of responses and continues with peeling conditions were responsible for the emergence of a response or behavior operands.

According to Skinner the most important element in learning is the reinforcement and punishment. Reinforcement and punishment. Reinforcement is a consequence that increases the probability that a behavior will occur. Instead, 
punishment is the consequence that decreases the probability of occurrence of a behavior (Suprijono, Agus, 2011: 99). For adults who are illiterate, literacy skills are not just able to read, write and count, but more emphasis function in everyday life. Functional Literacy is a business school education in teaching illiterate citizens to have been able to write, read and count for the purpose in everyday life by utilizing the existing resources in the surrounding environment, to improve the quality and standard of living. Priority illiterate people aged 15-50 years old in the eradication of illiteracy through functional literacy program. Illiterates are people who do not have the abilities to read, write and count and its application in everyday life. Based on study results, the residents learned KF program, consisting of two characteristics that are derived from pure illiterates and Droup Out Primary School, who still require literacy education services to meet the literacy competencies to solve problems encountered in daily life. Thus, functional literacy focused on the issue, directing the learning experience on the problems faced by the citizens learn in everyday life. Eradication of illiteracy has stages, namely, the stage of basic literacy and literacy stage independently. Stage basic literacy is the learners who do not have basic knowledge of calistung (reading, writing and counting) but have had the experience that can be used as learning activities. Lastly, the stage is independent literacy learners have the knowledge and experience. On the results of learning, learners are expected to analyze and solve problems in order to improve their standard of living.

Functional Literacy has the function of developing the basic human skills that include reading, writing and arithmetic that are functional in improving the quality and standard of life and society. "The primary purpose of functional literacy program is membelajarkan citizens to learn in order to utilize the basic ability to read, write, and count (calistung) and functional ability in daily life. (Competency Standards Vernacularly, 2006: 12)"

The essence of functional literacy learning centers on issues, interests and needs of the learning itself. The substance of learning material based on activities to assist them in implementing the skills and knowledge possessed. Functional literacy program can be as good as in accordance with the needs of each region, the functional literacy learning should refer to the following principle: the local context, local design, participatory process and functionalizing the learning outcomes. The principles are very influential on functional literacy learning process. Tutor together learners should be able to notice how the implementation of these principles. (Tom Burkard, 1999: 71).

Literacy programs conducted by various methods and approaches by the institutions with the aim of providing interest learners who are their age between 15-55 years. The methods and approach taken varies considerably according to the design of a local context where the implementation of the program. Literacy program followed by activities such functional, made of soap or activities to increase residents learn life skills. This SKKD covers several aspects, namely, 1). Hear; 2). Speaking; 3). Read; 4). Write; and 5). Numeracy. Overall SKKD revised aspect relates to everyday life and meaningful to learners. The revised SKKD have been published containing Kempetensi Standard Basic Literacy Education Graduates (SKL - PKD). SKL - PKD is intended as a qualified ability of citizens to learn after attending basic literacy program that covers the knowledge, attitudes and skills. SKL - PKD outlined in the standards of competence and further elaborated in the basic competencies. SKL - PKD consists of five standards of competence in accordance with SKKD, ie competence standards listening, speaking, reading, writing, and arithmetic. (Den Hartog, D. N., House, R. J., Hanges, P. J. et al., (1999).

\section{RESEARCH METHODS}

This research was conducted in Gorontalo province, carried out during the year, namely 2015-2016. This research is classified in this type of development research, because this research will be developed learning model. This research activity is designed to apply the approach to research and development. Research and Developmet ( $R$ \& D) is as a strategy that aims to improve the quality of education. Research using R \& D approach aims to develop and validate the results of education and to discover new knowledge through basic research. This study is also intended to answer specific questions about the problems of a practical nature through 'applied research' which is used to improve educational practices.

The steps in the execution of R \& D are: (1) begins with researching and gathering information, through the reading of literature, observation, and prepare a report on the needs of development, (2) planning and making prototype components that will be developed, including defining the capabilities / skills that will be developed, formulate goals, menentuan sequence of events, as well as making the measurement scale specifically, (3) develop an initial prototype, such as preparing textbooks and lift the evaluation, (4) conduct limited testing of the initial model, (5) revise the initial model , (6) conduct field trials, (7) to revise the results of the trial, (8) to operationalize the model that has been tested, (9) did the final revision to the model, and (10) the dissemination or distribution models.

In this study, the research subjects are illiterate residents learned basic level in Gorontalo province. Learning development models used in this study refers to the 4-D model of the proposed Thiagarajan, and Semmel Semmel (1974), which consists of four stages. The fourth stage is define, design, develop and disseminate stage.

Collecting data in this study using techniques of observation, interviews, questionnaires and documentation. Data analysis techniques used in this research is descriptive analysis techniques, and to determine the completeness of learning outcomes assessment system used initial score obtained from the pretest and the final score obtained from the posttest.

\section{RESULTS AND DISCUSSION}

Activities tutor in the classroom include two main points, namely teaching and managerial activities. Teaching activities directly intended Rouse learners achieve learning goals. Teaching activities, among others, such as examining the 
needs of learners, preparing lesson plans, presenting the material, ask questions, and assess student progress. Managerial activities intended to create and memeprtahankan grade classroom atmosphere so that teaching and learning can take place on an ongoing basis. Among other managerial activities, such as developing good relationships between tutors and learners, provide rewards quickly, develop rules of the game in group activities, termination behavior of learners distorted or not in accordance with regulations.

Destination management class is as follows: 1) Realizing the situation and condition of the class, either as a learning environment and as a group learning that enables students to develop skills as much as possible. 2) Eliminate the obstacles that may hinder the realization of teaching and learning interactions. 3) Provide and organize the facilities and furnishings that support learning and enable students to learn in accordance with the social, emotional, and intellectual student in the classroom. 4) Fostering and guiding in accordance with the social, economic, cultural as well as the properties of the individual.

Classroom management skills are the skills tutor to create and maintain an optimal learning conditions and skills to restore optimal learning conditions. In this case, including any attempt to maintain discipline tutor or engagement class (timely entrance, sitting at the right place, adherence to the tutor, glancing right and left, not noisy, and others). By organizing all resources will create a classroom learning process effective and efficient (Tom Burkard, 1999).

For learners and tutors, classes should be seen as a special place that should always be fun in it. To achieve these objectives, the tutor should create a classroom atmosphere that is fun and effective learning. Before doing the learning process in the classroom, tutor shall make or enforce rules. Classes that there are no rules in it will affect the attitude of the learners. They tend to be difficult to control or permissive and anarchic. When this occurs, learning becomes ineffective and the class is not fun. (Grootaert, C., Bastelaer, T.V., 2002).

Tutor fun not tutor permissive or allow any behaviors do learners in the classroom. Tutor fun always make and enforce the rules so that students still enjoy as well as produce a good output from the learning process.

In view of that, then before the learning process take place, the tutor should lead learners to organize the classroom situation. If the classes in a dirty, should be cleared in advance by learners. Similarly, if the state of the tables and chairs in an irregular, learners can fix it.

If the tutor will use a method that requires the preparation of a class, the class should have been prepared in accordance with the method used before learning takes place. That way, the learning time is not used up because it must first be compiled classes. Involve all students in the process of preparing the class. Classes can also be arranged according to the tastes of students, not to be conventional. Classrooms can be decorated in such a way that it can be a medium to facilitate the learning process. Given the climate and atmosphere of the class greatly affect the comfort in learning, tutor should pay attention to this. This includes also the seating arrangement learners so that the learning communication process becomes lively and interesting. Psychologically, everyone has a need to be appreciated and acknowledged. Likewise learners. They require respect for the achievements or the good they do the slightest.

Methods and instructional media selected tutor according to the type of material or competencies to be achieved as well as the circumstances of learners. Therefore, the use of methods and media learning should be appropriate and varied. The use of instructional methods and media are not appropriate and less variable can cause learning ineffective and inefficient. As a result, learners feel bored while studying and tutors also feel uncomfortable membelajarkan the material.

To be able to select and vary the methods and media appropriate learning, a tutor must have a broad knowledge of various methods and media with their respective characteristics. Do not let tutor wrong in determining both. One determines methods and learning media is very disturbing the learning process in the classroom. To create an interesting learning process, the tutor should still be able to vary the use of methods and media appropriate learning. Psychologically, people tend to like the new stuff. If someone is in a situation that monotone, he quickly feel tired and bored. So, variety is the key to creating the novelty and pleasure. Variation is also the key to creating dynamics.

\section{CONCLUSION}

Basic literacy education is an education for citizens who are illiterate to read, write, calculate, Indonesia, and the knowledge base that can provide opportunities to actualize themselves. The service is realized in an integrated literacy education with efforts to improve the social, economic, and cultural more helpful and empowering the community with a more effective and efficient. Accelerate completion of illiteracy using the basic level would be more effective locally specific and that efisen whom use Walama lo Tihedu Buhuta approach which is locally specific Gorontalo province, where all the elements of village officials empowered tutor in accelerating the completion of illiteracy. Through the completion of the activities of the neighborhood will be faster illiterate realized this is due to know each other between citizens who are in the territory of the hamlets or neighborhoods where their sense of caring and kinship among them.

Completion illiteracy together in such a responsibility, especially for the village head and the head of the neighborhood (RT) or chairman of the village (Kadus) that knowing the exact condition of the society must play an active role in running the program. Implementation of the program of completions illiterate elementary level across the province of Gorontalo to use Buhuta approach Walama Lo Tihedu.

\section{REFERENCES}

[1] A.G. Lunandi . 1982. Pendidikan Orang Dewasa: Sebuah Uraian Praktis untuk Pembimbing, Penatar, Pelatih dan Penyuluh Lapangan. Jakarta: Gramedia

[2] Baharudin dan Nur Wahyuni, 2008. Teori Belajar dan Pembelajaran. Yogyakarta: Ar-Ruzz Media. 
[3] D.Sudjana. 1993. Pendidikan Luar Sekolah: Wawasan, Perkembangan, Falsafah Dan Teori Pendukung, Serta Azas. Bandung: Falah Production.

[4] Hadi Supeno. 1999. Pendidikan Dalam Belenggu Kekuasaan. Magelang: Pustaka Paramedia.

[5] Knowles, M. 1978. The Adult Learning: A Negelected Species. Houston: Golf Publishing, Co.

[6] M. Ngalim Purwanto. 2002. Psikologi Pendidikan. Bandung. Remaja Rosda Karya.

[7] Sumarno. 1999. Tinjauan Terhadap Kurikulum Jurusan Pengembangan Masyarakat Islam. Yogyakarta: Makalah Sarasehan. Pengembangan Jurusan PMI.

[8] Suprijono, Agus, 2011. Cooperative Learning; Teori dan Aplikasi Paikem, cet. ke-5. Yogyakarta: Pustaka Pelajar.

[9] Suryabrata, Sumadi, 2014. Psikologi Pendidikan, cet. Ke-21, Jakarta: Rajagrafindo Persada

[10] Syamsu Mappa \& Anisah Basleman. 1994. Teori Belajar Orang Dewasa. Jakarta: Departemen Pendidikan dan Kebudayaan.
[11] Tom Burkard, 1999. Understanding and Facilitating Adult Learning, San Fransisco: Josey Bass Publlishers

[12] Dadhich and K. T. Bhal,, (2008) Ethical Leader Behavior and LeaderMemberExchange as Predictors of Subordinate Behaviors, Journal for Decision Makers, 33 (4)

[13] Den Hartog, D. N., House, R. J., Hanges, P. J. et al., (1999) "Culture speciŽ c and crossculturally generalizable implicit leadership theories: are attributes of charismatic/transformational leadership universally endorsed?". Leadership Quarterly 10(2): 219-56.

[14] Fabi, B.; Raymond, L. \& Lacoursiere, R. (2014) Hrm practice in relation to size and performance: An empirical investigation in Canadian manufacturing smes. Journal of Small Business and Entrepreneurship, $20(1), 25-39$.

[15] Grootaert, C., Bastelaer, T.V., 2002, Understanding and measuring social capital: a multidisciplinary tool for practitioners, Volume 1, World Bank Publication 